\title{
食品中のセレニウムの定量法とその含有量
}

\section{On the Selenium Content in Foods and Its Analysis}

(昭和 42 年 6 月 14 日 受 理)

後 藤 た
(Tae Goto)

The selenium content in foods was determined by fluorescent analysis, involving the wet decomposition of organic compounds at low temperature avoiding the vaporization loss of selenium.

The correction for the reagent blank was necessary.

The selenium contents obtained were $1.807 \mathrm{ppm}$ in dried garlic, $1.481 \mathrm{ppm}$ in green onion, and 0.945 . ppm in tangle.

緒 言

セレニウム（以下 Se とす）はV.E 欠症状の一部に

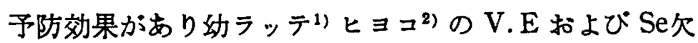
そ食慨に Se またはV.E を投与すると成長がよくな

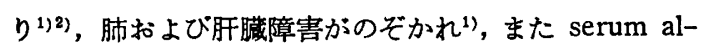
bumin levels を增加するとい $5^{2)}$ 。ヒヨコの成長に必 要な Se の量についてるくわしく報じられている2゙しヒ ナに $1 \mathrm{ppm}$ 以下の $\mathrm{Se}$ 投与は間接に筋萎縮症を防止 し, V.E 効力を增強するとい $5^{3)}$ 。

また Zaekin ら4)は Se-methionin, Se-cystein など Se の有機結合物が Antioxidant の働きを有すると報じ ている。これらに関係する報告は外国に多数見受けられ るが日本にはあまりみられない。しかも近時 V.E の生 理的効果およびその体内での機作についての報告が多く なったのでそれらと関係する Se についてその定量法お よび日本の一部食品中の含有量をしらべたのてここに報 告する。

\section{実 験 方 法}

1. 試料: ニンニク, 日本ネギ, ニラ, 玉ネギ, 昆布, フキノトウ,フキ, ウド, ホウレン草,ナス, ウルイ, シドケ, シブ柿

2.試薬》ならびに装置 :

・試薬 3,3'-ジアミノベンゼン, ジンクジチオール, エチルアルコール, 硝酸, 過酸化水素, 塩酸, エチレンクロライド, 四塩化孷素, 過塩素酸, 䗷酸, タタレゾールプェープル,アンモニヤ，
トルエン, 無水酸化カルシゥム, 西セレン酸,

・製置 送風乾燥機, 湿式分解用サンドバス（図 1 参

照) 營光湘定機 (Fluorophotometer F.:PL-2

型)

図1. 湿式分解用サンドバス

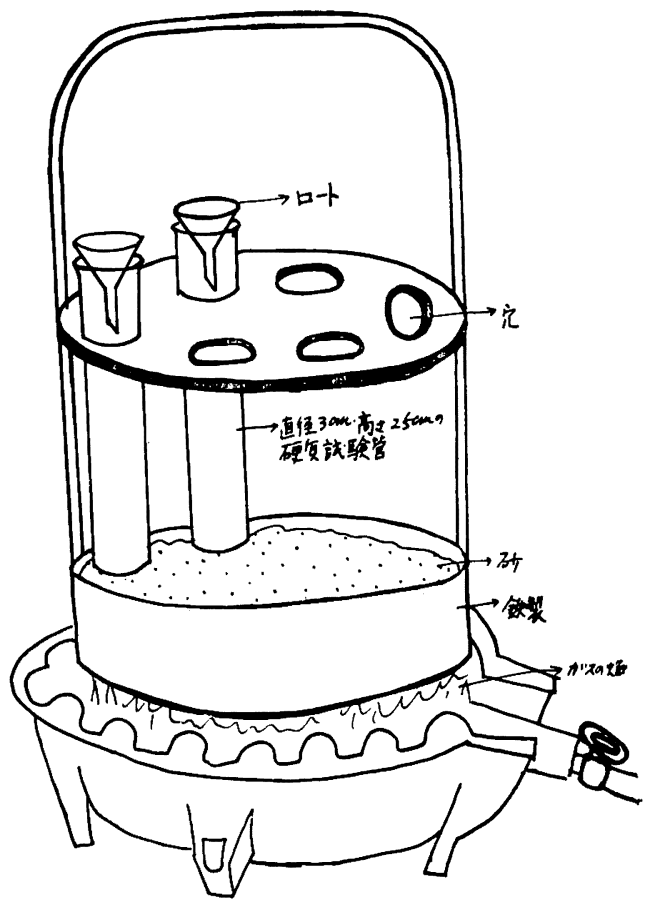

3. 食品中の Se の定量法

J.H. Watkinson 法らによったが, 食品の乾燥および 


\section{栄養と食粗}

分解は特に Se の散逸をふせぐことに苦心した。また処 理後の最終におけるセレナチフジールの㷥光測定は 436 $\mathrm{m} \mu$ の光をあて, $470 \mathrm{~m} \mu$ の band で行なった。さらに 各試薬の盲螢光も故密にしらべた。用いた試薬の量もい くらか異なる。

次に Se の定量法をくわしくのべる。

食品を $50^{\circ} \mathrm{C}$ 以下で送風乾燥しのち粉末試料とする （原著には $40^{\circ} \mathrm{C}$ 以下とあるが乾燥しにくい。 $50^{\circ} \mathrm{C}$ 以 下で Se は散逸しない)。Se $0.02 \mathrm{ppm}$ 以上含む試料を $3 \times 25 \mathrm{~cm}$ の硬質試験管に移す。それに $10 \mathrm{ml}$ の濃硝酸 を加え室温に一夜放置する。のちその試料入り試験管を 図1に示すごとくさし込み, 弱火で加熱する。試験管の上 にロートをのせて蒸気の散逸を防ぐと共に逆流冷却装置 と同じ働きをして, 硝酸が減少しないままで分解が続行 される。（この方法は食品の有機物分解に際し常に便利 なので Se 以外の定量時にも用いている。)半分解後, 放 冷して70\%過酸化水素を $5 \mathrm{ml}$ 加える。試料が完全に酸 化すると中の溶液が無色透明になる。後口ートを除去し て加熱をつづける。白煙の出てくるまで加熱してこの白 煙をすっかり除去する。次に放冷し試験管の器壁を洗 5 （硝酸をよくおとすため）。再び白煙の出てくるまで加熱 しさらに硝酸を追い出す。（硝酸はジチオールと反応す るから完全に除去しなければならない。)のち水 $15 \mathrm{ml}$ 加えさらに $96 \%$ エチルアルコールの $4 \mathrm{ml}$ を加えて温め る。のち塩素酸カリウムの結晶放出をみとめるまで室温 で冷す。それを $100 \mathrm{ml}$ の分液ロートに沪過する。その 時沪杜をでく洗い最後の容䅞を $35 \mathrm{ml}$ にする。こ の $35 \mathrm{ml}$ に濃塩酸の $50 \mathrm{ml}$ とジンクジチオールのサス ペンション（1\%サスペンション $96 \%$ エチルアルコール) $4 \mathrm{ml}$ を加える。15 分後セレニウムコンプレックスを10 $\mathrm{ml}$ の次の液—50\% ずつ混合した エチレンクロライ ドと四塩化炭素せ一中に抽出する。その有機層を前と同 じ試験管に集める。さらに $5 \mathrm{ml}$ の同溶剛で抽出してさ きの $10 \mathrm{ml}$ 抽出液と混合する。これに $70 \%$ の過塩素酸 $1 \mathrm{ml}$ を加え 10 滴の硝酸を入れロートでふたをして静か に加熱し（ウォーターバス中で）有機凮を蒸発させると 同時に前と同じに白煙の出るまで分解する。のち $20 \mathrm{ml}$ の水を加える。次に $2.5 \mathrm{M}$ の蟻酸溶液の $2 \mathrm{ml}$ とメタ クレデールプァープル溶液の 1 滴を加える。それに $7 \mathrm{M}$ のアンモニア溶液を 指示薬が黄色になるまで（約 15〜 16滴）滴下する。次にジフミノベンジン $0.5 \%$ 水溶液 （使用の都度つくる）を $2.3 \mathrm{ml}$ 加える。 $45 \mathrm{ml}$ にうす めて 30〜40 分室温に放置する。次に $7 \mathrm{M}$ フンモニア水 を紫色になるまで滴下する (約10滴)。これを $50 \mathrm{ml}$ に らすめる。次にこの液を分液ロートに取り $10 \mathrm{ml}$ のトル エンを加え，セレンジフジールを抽出する。ふたつき試
図 2. Se の標準曲線 $(0.1 \mathrm{ppm}-0.8 \mathrm{ppm})$

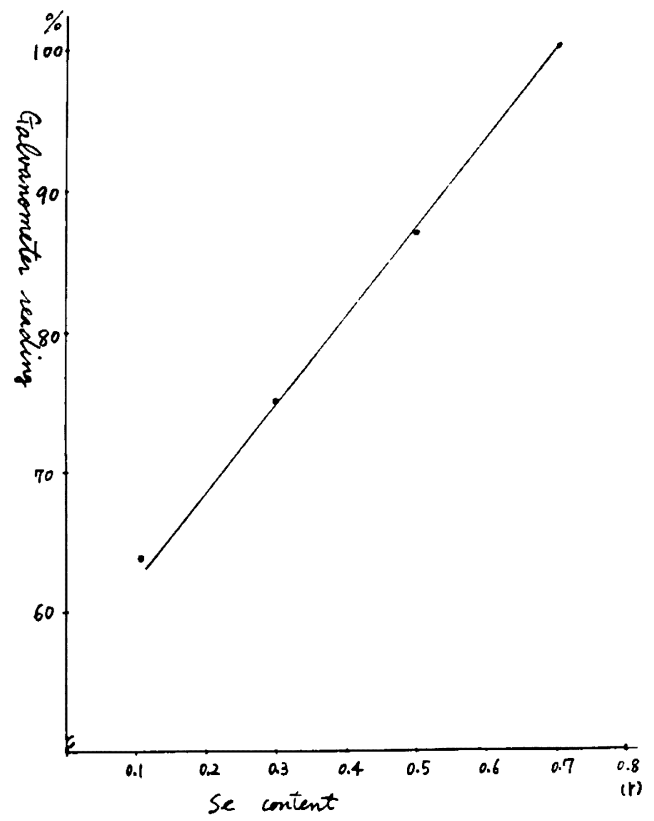

図 3. Se の標準曲線 $(0.05 \mathrm{ppm}-0.1 \mathrm{ppm})$

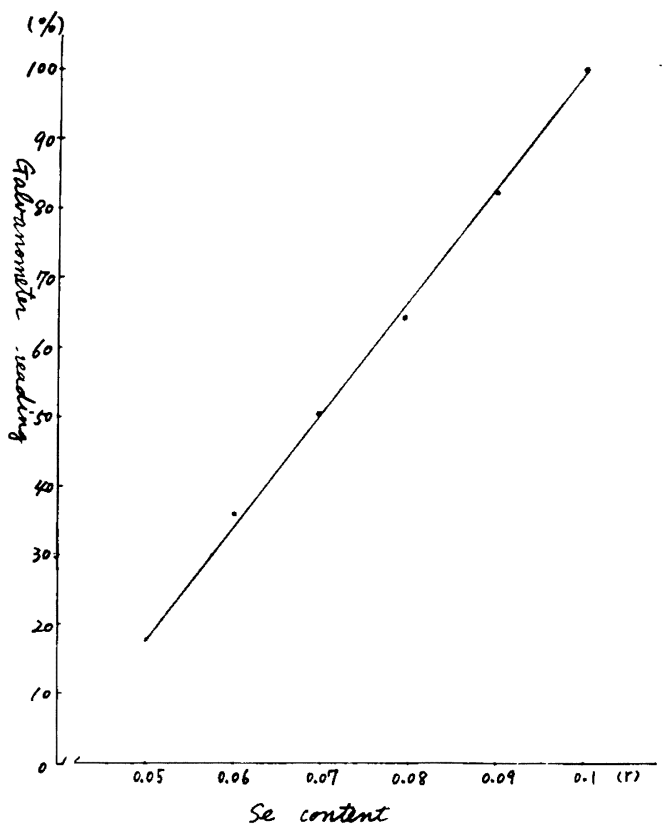

験管にトルェンをちくびピペットで移し無水塩化カルシ ウムの少量 $(2 \sim 3 \mathrm{~g})$ を入れてょく振る。

トルエン中のセレナチフジールに $436 \mathrm{~m} \mu$ の光を照射 し $470 \mathrm{~m} \mu$ の band で䖝光を測定する。ブランクテス トを行ないこの盲螢光をさし引く。 


\section{4. 標準曲線の作成}

上述の分解用試験管に $100 \mathrm{mg}$ の $\mathrm{Se}$ をとり濃硝酸 10 滴を加え 1 夜放置後 $70 \%$ 過塩素酸 $1 \mathrm{ml}$ を加え小口 一トをのせ上述同様白煙の出るまで加熱する。硝酸を完 全に追い出し放冷後水を加えて $1 \mathrm{ml}$ 中 $\mathrm{Se}$ が含 $1 \mathrm{ppm}$ 有するようにうすめる。これを用いて試料と同様な処理 を行ない $0.1 \mathrm{ppm}$ から $0.8 \mathrm{ppm}$ ならびに $0.05 \mathrm{ppm}$ か ら $0.1 \mathrm{ppm}$ までの螢光を测定して標準曲線を図 2 , 打 よび図 3 のごとく作成する。

\section{実 験 結 果}

\section{植物性食品中の Se 含有量}

上記の実験法によりニンニク, 日本ネギ, ニラ, 玉ネ ギ, 昆布, フキノトウ, フキ, ウド, ホウレン草, ウル イ, ナス, シドケ, シブ柿中の Se 含有量を测定したと ころすべて乾燥試料中 ニンニク $1.807 \mathrm{ppm}$, 日本ネキ゚ $1.481 \mathrm{ppm}$, ニラ $0.750 \mathrm{ppm}$, 玉ネギ $0.371 \mathrm{ppm}$, 昆布 $0.945 \mathrm{ppm}$, フキノトウ $1.737 \mathrm{ppm}$ 、フキ $1.533 \mathrm{ppm}$, ウド $0.240 \mathrm{ppm}$ ，ホウレン草 $0.392 \mathrm{ppm}$, ウルイ 0.259 表 1 . 植物性食品中の Se 含有量

\begin{tabular}{|c|c|c|c|}
\hline 食品名 & $\begin{array}{c}\text { 乾燥物中 } \\
\text { の含有量 } \\
\text { (ppm) }\end{array}$ & $\begin{array}{l}\text { 生 } 100 \mathrm{~g} \\
\text { 中の含有 } \\
\text { 量 }(r)\end{array}$ & 備 考 \\
\hline$=v=\eta$ & 1.807 & 90.3 & 市 販 \\
\hline 日本ネギ & 1.481 & 30.8 & 同上 \\
\hline$=$ & 0.750 & 6.4 & 同上 \\
\hline 玉 キ キ & 0.371 & 3.4 & 同上 \\
\hline 昆布 & 0.945 & 86.9 & 同上 \\
\hline フキノトウ & 1.737 & 54.2 & 野 生 \\
\hline$\neq$ & 1.533 & 19.9 & 野 生 \\
\hline ウ & 0.240 & 2.5 & 市 販 \\
\hline ホウレン草 & 0.392 & 5.3 & 同上 \\
\hline ウ ル イ & 0.259 & 3.6 & 同上 \\
\hline ナ & 0.786 & 6.7 & 同上 \\
\hline シ ドケ & 2.387 & 44.2 & 市 販 \\
\hline シブ 柿 & 1.117 & 29.4 & 直接採取 \\
\hline
\end{tabular}

注 : 含有量は 3 回測定の平均値である ppm, ナス $0.786 \mathrm{ppm}$, シドケ $2.387 \mathrm{ppm}$, シブ湘 $1.117 \mathrm{ppm}$ であった。詳しく表 1 に示す。

表 1 によるごとく Se は生試料の場合ニンニク, 昆布 などに多く，フキノトウ，シドケ，日本ネギおよびシブ 柿，フキ中にも比較的多く含まれている。ナス，二ラ， ホウレン草, ウルイ, 玉ネギ, ウドなどの中には少量で 約 $3 \sim 7 r$ 含有にすぎない。

$$
\text { 要旨 }
$$

食品の Se の定量は乾燥および有機物分解特に Se の 飛散を防止しなければならない。また篮光分析にあたっ ては試薬の盲煏光を注意しなければならない。食品中二 ンニク, 日本ネギ, フキノトウ, シドケ, フキなどに Se が多く含まれ昆布にも特に多く含まれている。それ らはいずれも乾燥試料て $2.4 \mathrm{ppm}$ から $0.95 \mathrm{ppm}$ の間 の Se 含有量である。

\section{考察}

今回の二ラ, 玉ネギなど分析値は文献値 ${ }^{5)}$ のLeek(二. ラネギ), Onion bulb に比へてやや多い。しかし品種も 異なるだろうし，また生育した土鼠にもよることと思う。 ただ Se の動きは硫黄の動きと相似であるから硫黄を含 むニンニクなどに Se が多いのは何かこの間の関連も考 えられる。

本実験の分析法の指導を賜った東北大学金属材料研究: 所助教授杮田八千代博士に感謝の意を表す。

\section{文 献}

1) Seward, C. R., Vaughan, G., Hove, E. L.: Proc.. Soc. Exp. Biol. Med., 121, 850 (1966)

2) Nesheim, M.C., Scott, M. L.: J. Nutrition, 65, 601 (1958)

3) Desai, I. D., Scott, M. L.: Arch. Biochem. Biophys., 110, 309 (1965)

4) Zaekin, H., Tappsll, A.L.: Arch. Biochem. Biophys., 91, 117 (1960)

5) Watkinson, J.H.: Anal. Chem., 32, 981 (1960)

(宮城学院女子大学), 